\section{Occasional Surveys}

\section{DIET AND THE GEOGRAPHICAL DISTRIBUTION OF MULTIPLE SCLEROSIS*}

\author{
BERNARD W. AgranofF DAVID Goldberg
}

Department of Biological Chemistry and Population

Studies Center, University of Michigan, Ann Arbor, Michigan 48104, U.S.A.

\section{Summary Data are presented to suggest that a} geographical predisposing factor (G.P.F.)
in multiple sclerosis (M.S.) may reflect regional dietary differences, and, further, that this factor is directly related to milk production or consumption. A number of biochemical hypotheses are proposed which would predict a resultant weakened blood-brain barrier or immunological defence, or the production of defective myelin, which would then increase susceptibility to the ætiological agent, possibly a virus. From the standpoint of brain development, two different ideas emerge-one, that differences in the composition of bovine and human milk, particularly during weaning, lead to the G.P.F.; the other, that drinking of milk beyond the normal nursing period is detrimental. More epidemiological studies are needed, with emphasis on diet, especially during periods of rapid brain development. Cow's milk may be an unfortunate substitute for human milk in infancy or a risky food source thereafter, or both. Epidemiological data raise these questions but do not provide ready answers. The milk correlation could be spurious, but at least ideas based on such a correlation pay attention to the most important epidemiological clue in M.S.-namely, the geographical distribution of the disease.

\section{INTRODUCTION}

THE peculiar geographical distribution of multiple

\footnotetext{
* Presented in part at the fifth annual meeting of the American Society for Neurochemistry, held in New Orleans on March 13, 1974.
}

DR HOLT: REFERENCES-continued

42. Miller, M. H. Clin. Pediat. 1971, 10, 340

43. Reynell, J. K. Reynell Developmental Language Scales. National Foundation for Educational Research, Windsor, 1969.

44. Sheridan, M. D. Clins devel. Med. 1969, no. 3a, p. 39.

45. Keith, C. G., Diamond, Z., Stansfield, A. Br. F. Ophthal. 1972, 56, 827.

46. Gardiner, P. Report to D.H.S.S. subcommittee, 1970

47. Rutter, M., Graham, P. Proc. R. Soc. Med. 1966, 59, 382.

48. Mitchell, S., Shepherd, M. Br. F. educ. Psychol. 1966, 36, 248.

49. Rutter, M., Graham, P., Yule, W. A Neuropsychiatric Study in Childhood. National Foundation for Educational Research, Windsor, 1970

50. Randall, D., Reynell, J., Curwen, M. Br. F. Dis. Comm. 1974, 9 , 3.

51. Alberman, E. Devel. Med. Child Neurol. 1973, 15, 202.

52. Bax, M., Mac Keith, R. (editors). Minimal Cerebral Dysfunction (Clins devel. Med. no. 10). London, 1963.

53. Kohen-Raz, R. Pediatrics, 1971, 47, 153.

54. Department of Health and Social Security. Report of the Expert Group on Special Care for Babies. H.M. Stationery Office, 1971

55. Davies, P. A., Robinson, R. J., Scopes, J. W., Tizard, J. P. M., Wigglesworth, J. S. Clins devel. Med. 1972, no. 44/45.

56. Thomas, A., Chesni, Y., Dargassies, S. S-A. ibid. 1960, no. 1.

57. Prechtl, H., Beintema, D. ibid. 1964, no. 12

58. Illingworth, R. S. ibid. 1962 , no. 3 .

59. Court, S. D. M., Jackson, A. D. M. Pxdiatrics in the Seventies. London, 1972 . sclerosis (M.S.) has long been a puzzle to researchers. Within a country, such as the United States, which spans a great range of latitude, M.S. is more frequent in colder regions, ${ }^{1}$ and evidence from different countries suggests low rates near the equator and increasing rates in temperate zones, with a possible decline beyond 50-60 degrees of latitude. ${ }^{2}$ While the atiology and pathogenesis of M.S. remain uncertain, it is often suggested that the disease may be initiated by a virus ${ }^{3}$ and that its progression may be mediated by autoimmunity. A world map of M.S. shows why epidemiologists have selected aspects of industrialisation such as sanitation, ${ }^{5}$ medical facilities, ${ }^{6}$ socioeconomic status, ${ }^{7}$ and $\operatorname{diet}^{8}$ as potential explanations underlying the correlation between M.S. and laticude, temperature, and sunlight. ${ }^{9}$ The putative geographical predisposing factor (G.P.F.) may be instituted early in life, since those who emigrate after adolescence to a country with a low incidence of M.S. seem to carry risks associated with their country of origin. ${ }^{10}$ Of possible relevance is the rare finding of pathological evidence of M.S. in the brains of adults who have died of an unrelated disease. ${ }^{11}$ Since dairy-food production and consumption is greater in colder climates within the temperate zone, we wondered if some aspect of milk consumption could explain the G.P.F. Rather than using the conventional epidemiological procedure of simply reporting correlations between the variables selected for study and M.S., we ask whether dairy consumption makes a significant contribution to the explanation of M.S. after controlling for geographical factors and other variables known to be correlated with M.S. Is milk consumption simply a variable whose effect can be accounted for by other variables, or does it resist statistical elimination?

APPROACHES TO THE EPIDEMIOLOGY OF M.S

Of the usual numerical representations of the disease (prevalence, incidence, and mortality) we chose mortality for a study of the disease in the U.S. Mortality data have some disadvantages. An unknown fraction (perhaps quite large) of deaths due principally to M.S. is not so specified on death certificates. ${ }^{12}$ If there are substantial differences in expectation of life at birth, similar mortality-rates for different regions could represent substantial differences in prevalence. Also, if the G.P.F. exerts its effect at an early age, there is about a 30-60 year gap between the predisposing event(s) and death, which should be taken into account. For example, if a dietary study is correlated with M.S., mortality-rates in 1960 should reflect the diet in 1900-30. Despite these drawbacks, mortality data do have the important advantage that they are uniformly available for all American States from 1949 , creating a stable data base that is unobtainable from occasional studies of prevalence or incidence. We have used all M.S. deaths in the 48 contiguous States for the period $1949-51,1953-57,1958-62$, 1963-67-a total of about 26,000 deaths. ${ }^{13}$ To eliminate the effects of age, race, and sex, we calculated an expected number of deaths for each State by multiplying the age, race, and sex distribution of each State by the specific rates for the U.S. within each period. Our main dependent variable is the ratio of actual M.S. deaths to expected M.S. deaths for each State. 
For additional stability, we have averaged the four period ratios.

\section{STUDIES IN THE U.S.}

Examination of the relationship between latitude and the standardised M.S. mortality ratio for Whites showed that States like Alabama, Georgia, and Tennessee have only about $50-60 \%$ of their predicted (expected) deaths based on age, sex, and race, while States such as Wisconsin, Oregon, and Iowa have $40-50 \%$ more than their expected share. The correlation between latitude and M.S. is 0.90 . When per-caput milk consumption ${ }^{14}$ is compared with the standardised M.s. mortality ratio the correlation is $\mathbf{0 . 8 2}$. Both are highly significant. Tables $I$ and II ${ }^{15-23}$ include only part of a larger study of four types of variables - milk, socioeconomic status, medical services, and climate or latitude. Our choice

TABLE I-CORRELATIONS OF SELECTED MEASURES OF MILK, MBDICAL SERVICES, SOCIOECONOMIC STATUS, AND CLIMATE WITH THE RATIO OF ACTUAL TO EXPECTED M.S. MORTALITY FOR AMERICAN STATES $1949-67 *$

\begin{tabular}{|c|c|c|}
\hline Selected independent variables & $\begin{array}{l}\text { Average } \\
\text { M.s. ratio, } \\
\text { total } \\
\text { population }\end{array}$ & $\begin{array}{l}\text { Average } \\
\text { M.s. ratio, } \\
\text { White } \\
\text { population }\end{array}$ \\
\hline Milk measures: & & \\
\hline $\begin{array}{l}\text { Cows and heifers/person }(1930)^{15} \ldots \\
\text { Cows and heifers/person }(1950)^{16} \ldots \\
\text { Relative per-caput milk consumption }\end{array}$ & $\begin{array}{l}0.57 \\
0.51\end{array}$ & $\begin{array}{l}0.58 \\
0.52\end{array}$ \\
\hline $\begin{array}{cccc}(1965) & \\
\text { Relative per-caput butter consump- }\end{array}$ & 0.81 & 0.82 \\
\hline 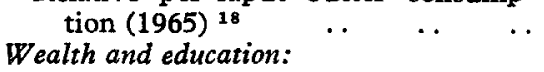 & $0 \cdot 71$ & 0.71 \\
\hline 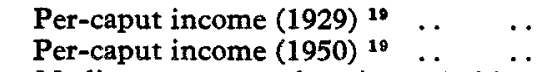 & $\begin{array}{l}0.37 \\
0.44\end{array}$ & $\begin{array}{l}0.36 \\
0.43\end{array}$ \\
\hline 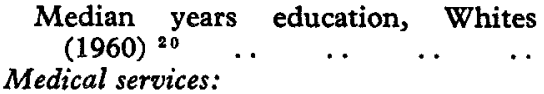 & 0.31 & 0.32 \\
\hline $\begin{array}{l}\text { Hospital beds/person (1945) }{ }^{21} \\
\text { Hospital beds/person (1969) } \\
\text { Nursing-home beds/person }(1970)^{20} \\
\text { Physicians/person }(1969)^{20}\end{array}$ & $\begin{array}{l}0.15 \\
0.37 \\
0.56 \\
0.21\end{array}$ & $\begin{array}{l}0.14 \\
0 \cdot 35 \\
0.58 \\
0 \cdot 21\end{array}$ \\
\hline Climate: & & \\
\hline $\begin{array}{l}\text { Average possible sunshine }{ }^{22} \\
\text { Normal monthly minimum tempera- }\end{array}$ & & -0.31 \\
\hline $\begin{array}{ccccc}\text { ture }^{22} & \ldots & \ldots & \ldots & \ldots \\
\text { Latitude }^{23} & \ldots & \ldots & \ldots & \ldots\end{array}$ & $\begin{array}{r}-0.83 \\
0.90\end{array}$ & $\begin{array}{r}-0.83 \\
0.90\end{array}$ \\
\hline
\end{tabular}

* The M.S. ratios used in the correlations are an unweighted average of the M.S. ratios for the periods 1949-51, 1953-57, 1958-62, and 1963-67, derived from the data given in ref. 13. Data on State populations, 1940-70,14 were combined with data on milk measures, $15-18$ socioeconomic status, ${ }^{19,20}$ medical services, ${ }^{20,21}$ and climate 32,23 to obtain measures of the independent variables. of variables other than milk was somewhat arbitrary, but was generally dictated by prior epidemiological studies. The illness is often described as a disease of affluence, but it has been hypothesised that the apparent highly patterned geographic distribution actually reflects differences in available medical care (i.e., M.S. is more likely to be diagnosed in an affluent population). Our U.S. data do not bear this out. The highest correlations were found with measures of milk and climate.

Correlations between the independent variables and the M.s. ratio for non-Whites were low. Differential reporting or instability resulting from the small number of actual and expected cases is probably responsible for the noted absence of any systematic relationship between White and non-White disease patterns. Non-White mortality is about a half of White M.s. mortality: if valid, this difference could be explained by differences in resistance or predisposition to M.S. ${ }^{24}$ or to a lower milk consumption in non-Whites, ${ }^{25}$ perhaps reflecting the occurrence of lactose intolerance. ${ }^{26}$

From only the zero-order correlations in table 1 , one might conclude that the correlations between milk measures and M.S. are spurious-i.e., that the reason for the correlation is that milk production and consumption are concentrated in colder climates. In the absence of a controlled laboratory experiment, one cannot determine whether or not the relationship is real. We can, however, determine through regression analysis whether the relation. ship between milk and M.S. is attributable to the correlation between milk measures and other variables or whether the milk measures have a unique impact on M.S. independent of the other variables in the regression equation (table II). The equations are dominated by climate (or latitude) and milk, whereas socioeconomic status and medical services do not have a significant impact on the M.s. ratio. Clearly, the relationship between milk and M.s. cannot be attributed to the relationship of milk with the other variables, including climate or latitude. Equations 3 and 4 show that a change of one standard deviation in the milk variable produces a change of 0.4 S.D. in the M.S. ratio after adjustment for the other three variables. When climate or latitude is eliminated (equation 5), milk is the only other variable that makes a significant contribution. While the correlation between milk-fat consumption and M.s. is strongly positive, the correlation between derived vegetable fat-oil consumption and M.S. is negative. Southern eating habits include greater consumption of shortenings, cooking oils, and salad dressing than in the North.18 Additional correlation and regression analyses that include other dietary components show a negative relationship between M.S. and

TABLE II-REGRESSIONS OF AVERAGE M.S. DEATH RATIOS FOR WHITES ON MILK, MEDICAL SERVICES, SOCIOECONOMIC STATUS, AND CLIMATE FOR AMERICAN STATES 1949-67

\begin{tabular}{|c|c|c|c|c|c|c|c|c|c|c|c|c|}
\hline \multirow[b]{3}{*}{$\begin{array}{c}\text { Equa- } \\
\text { tion }\end{array}$} & \multicolumn{11}{|c|}{ Standardised beta coefficients for: } & \multirow{3}{*}{$\begin{array}{c}\text { Multipla } \\
R\end{array}$} \\
\hline & \multicolumn{3}{|c|}{ Milk } & \multicolumn{3}{|c|}{ Medical services } & \multirow[b]{2}{*}{$\begin{array}{l}\text { Income } \\
(1950)\end{array}$} & \multicolumn{3}{|c|}{ Climate } & \multirow[b]{2}{*}{ Latitude } & \\
\hline & $\begin{array}{l}\text { Cows } \\
(1930)\end{array}$ & $\begin{array}{c}\text { Milk } \\
\text { con- } \\
\text { sump. } \\
(1965)\end{array}$ & Both* & $\begin{array}{c}\text { Nursing- } \\
\text { home } \\
\text { beds } \\
(1970)\end{array}$ & $\begin{array}{c}\text { Hospital } \\
\text { beds } \\
(1969)\end{array}$ & Both* & & Temp. & Sun & Both* & & \\
\hline $\begin{array}{l}1 \\
2 \\
3 \\
4 \\
5\end{array}$ & $\begin{array}{c}0.30 \\
0.24 \\
\ldots \\
\ldots \\
\ldots\end{array}$ & $\begin{array}{c}0.20 \\
0.19 \\
\ldots \\
\ldots \\
\ldots\end{array}$ & $\begin{array}{c}\ldots \\
0.44 \\
0.38 \\
0.82\end{array}$ & $\begin{array}{c}0.10 \dagger \\
0.06 \dagger \\
\ldots \\
\ldots \\
\ldots\end{array}$ & $\begin{array}{c}-0.05 \ddagger \\
0.01 \dagger \\
\ldots \\
\ldots \\
\ldots\end{array}$ & $\begin{array}{c}\ldots \\
0.09 \dagger \\
0.06 \dagger \\
0.01 \dagger\end{array}$ & $\begin{array}{r}0.08 \dagger \\
0.03 \dagger \\
0.04 \dagger \\
-0.01 \ddagger \\
0.08 \dagger\end{array}$ & $\begin{array}{c}-0.41 \\
\ldots \\
\ldots \\
\ldots \\
\ldots\end{array}$ & $\begin{array}{c}-0 \cdot 18 \\
\ldots \\
\ldots \\
\ldots \\
\ldots\end{array}$ & $\begin{array}{c}. . \\
0.46 \\
\ddot{.} \\
.\end{array}$ & $\begin{array}{c}\ldots \\
0.58 \\
\ldots \\
0.58 \\
\ldots\end{array}$ & $\begin{array}{l}0.92 \\
0.94 \\
0.91 \\
0.94 \\
0.87\end{array}$ \\
\hline
\end{tabular}

* Index constructed by regressing the two variables shown in the table on M.S.

+ Not statistically significant, $\alpha=0.05$ (one-tail).

Sign reversal. 
TABLE III-CORRELATIONS OF ANIMAL AND CROP PRODUCT FATS CONSUMPTION WITH M.S. LEVELS FOR THE O.E.C.D. COUNTRIES*

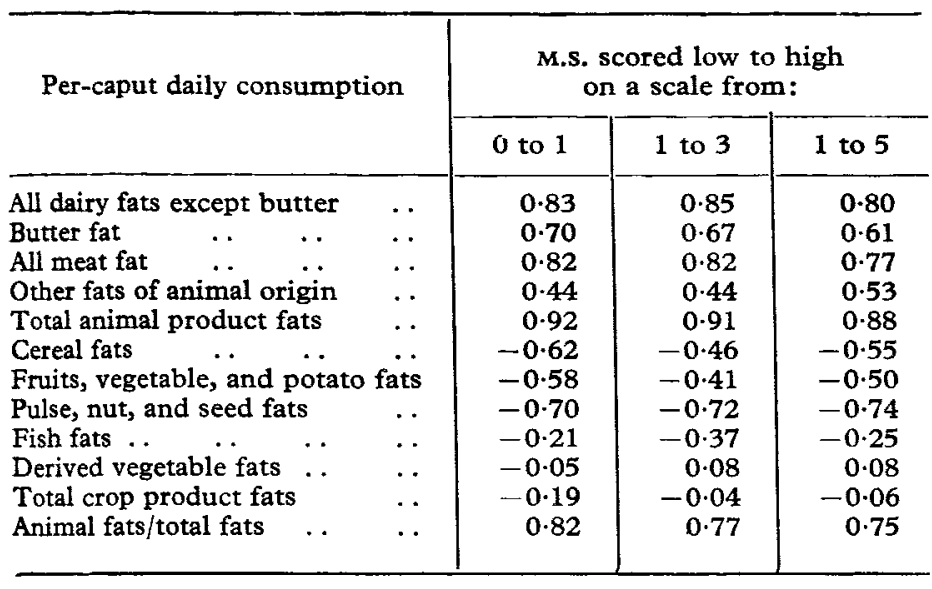

- Austria, Belgium, Canada, Denmark, U.K., Finland, France, Germany, Holland, Italy, Ireland, Japan, New Zealand, Norway, Portugal, Spain, Sweden, Switzerland, Yugoslavia, United States. Food-consumption data were obtained from ref. 27. Ordinal scales of M.s. risk were derived from refs. 28 and 29.

fish intake. Current milk fat consumption and a proxy for consumption in 1930 (milk production), however, remain as the most consistent correlative factors in our data, when several other dietary and non-dietary variables are used in the equations.

\section{STUDIES IN OTHER COUNTRIES}

Using food-consumption data for countries in the Organisation for Economic Cooperation and Development (O.E.C.D.), ${ }^{27}$ we performed an analysis similar to that done with the U.S. Comparable mortality, prevalence, or incidence data were not available for each country. We therefore utilised published maps of M.S. density ${ }^{28,29}$ from which we created rough ordinal scales of high, moderate, and low risks (table III). Although the published mappings provide only a rough scale of M.S. risk, the results from the U.S. were sufficiently intriguing to warrant an effort with less precise data. The contrast between the positive correlation of M.s. with animal-product fats and the negative one with products containing polyunsaturated fats is striking. In table IV we have assembled two groups of contrasting countries-the relatively wealthy O.E.C.D. group and the heterogeneous group of European and Near-Eastern countries used by Leibowitz et $a_{0}{ }_{0}^{30}$ in their analysis of M.s. among immigrant groups to Israel. The latter partly overcomes the problem of incomparable data from different countries and is based on a countrywide survey of M.S., including re-examination of patients by a team of neurologists, using fixed diagnostic criteria. The data for the ordinal scales of M.S. in the O.E.C.D, countries and the M.S. prevalence-rates in the other group of countries were compared with U.N. data ${ }^{31}$ for milk-product consumption, population per hospital bed, energy consumption, and latitude, corresponding roughly with the four variables used for the U.S. (tables IV and V). Results were similar to those seen for the American States, especially in the O.E.C.D. countries, where living standards are more comparable to those of the U.S. In this group of twenty-one countries, milk, even more than latitude, was the major statistical determinant of M.S. The importance of affluence and medical facilities as determining factors was again highly questionable.

TABLE V-REGRESSIONS OF M.S. ON MILK CONSUMPTION, HOSPITAI FACILITIES, ENERGY CONSUMPTION, AND LATITUDE FOR THREE SETS OF COUNTRIES

\begin{tabular}{|c|c|c|c|c|c|c|c|}
\hline \multirow{3}{*}{$\begin{array}{l}\text { Independent } \\
\text { variables }\end{array}$} & \multicolumn{7}{|c|}{ Standardised beta coefficients for: } \\
\hline & \multicolumn{2}{|c|}{$\begin{array}{l}\text { O.E.C.D. } \\
\text { countries }\end{array}$} & \multicolumn{3}{|c|}{$\begin{array}{l}\text { Israeli immigrant } \\
\text { countries }\end{array}$} & \multicolumn{2}{|c|}{$\begin{array}{l}\text { Combined } \\
\text { countries }\end{array}$} \\
\hline & $\begin{array}{l}\text { M.s. } \\
1-3\end{array}$ & $\begin{array}{l}\text { M.s. } \\
1-5\end{array}$ & $\begin{array}{l}\text { M.S. } \\
1-3\end{array}$ & $\begin{array}{l}\text { M.s. } \\
1-5\end{array}$ & $\begin{array}{l}\text { M.s. } \\
\text { Prev. }\end{array}$ & $\begin{array}{l}\text { M.S. } \\
1-3\end{array}$ & M.s. \\
\hline $\begin{array}{l}\text { Per-caput milk } \\
\text { consumption } \\
\text { Population per }\end{array}$ & 0.72 & 0.44 & 0.27 & 0.40 & $0.34^{*}$ & $0 \cdot 36$ & $0 \cdot 38$ \\
\hline $\begin{array}{l}\text { hospital bed } \\
\text { Per-caput energy }\end{array}$ & $0 \cdot 20 \dagger$ & $0.03 \dagger$ & $0.18 \dagger$ & $0 \cdot 18 \dagger$ & $0 \cdot 12 \dagger$ & $0 \cdot 14 \uparrow$ & $0.21 \dagger$ \\
\hline $\begin{array}{l}\text { consumption } \\
\text { Latitude }\end{array}$ & $\begin{array}{l}0 \cdot 18^{*} \\
0 \cdot 24\end{array}$ & $\begin{array}{l}0 \cdot 25 \\
0 \cdot 38\end{array}$ & $\begin{array}{l}0.48 \\
0.38\end{array}$ & $\begin{array}{l}0.33 \\
0.37\end{array}$ & $\begin{array}{l}0.31^{*} \\
0.36^{*}\end{array}$ & $\begin{array}{l}0.28 \\
0.48\end{array}$ & $\begin{array}{l}0.25 \\
0.52\end{array}$ \\
\hline Multiple $R$ & 0.92 & 0.88 & 0.95 & 0.93 & 0.87 & $\begin{array}{l}0.48 \\
0.93\end{array}$ & 0.92 \\
\hline
\end{tabular}

* Not statistically significant, $\alpha=0 \cdot 05$, one-tail

$\dagger$ Sign reversal.

In comparing Israeli immigrants from developed countries such as Britain, Germany, and Holland with those from underdeveloped countries such as Yemen, Libya, and Egypt, we obtained a somewhat different result. Table $\mathrm{v}$ shows that in addition to milk and latitude, affluence does seem to contribute to M.S. prevalence. The striking similarities involved in correlation and regression when using either prevalencerates for Israeli immigrants or the rough ordinal scales derived from maps should be noted. Leibowitz et al. noted a high rate of M.S. among native-born Israelis. ${ }^{32}$ This may reflect the high consumption of dairy products in Israel relative to Middle Eastern countries. ${ }^{31}$

TABLE IV-CORRELATIONS OF MILK CONSUMPTION, HOSPITAL FACILITIES, ENERGY CONSUMPTION, AND LATITUDE WITH SELECTED MEASURES OF M.S. FOR THREE SETS OF COUNTRIES

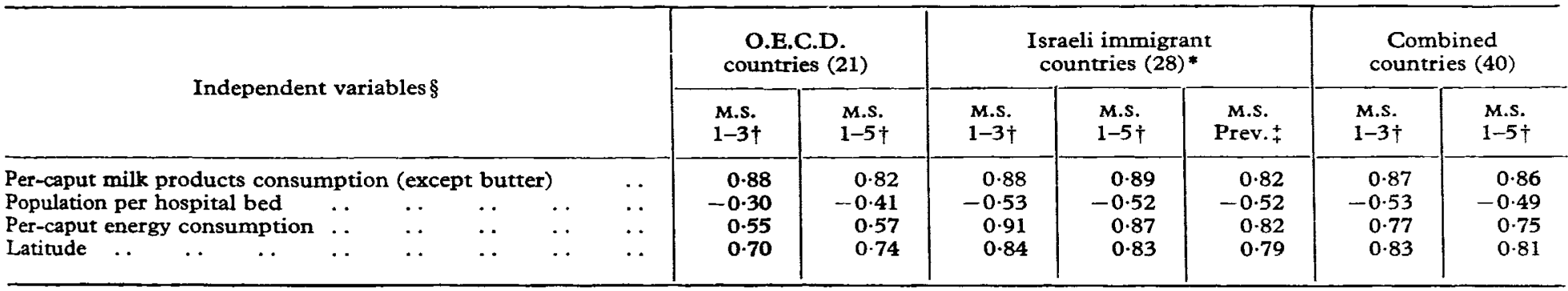

* The Israeli immigrant countries are Aden, Algeria, Austria, Bulgaria, Czechoslovakia, Denmark, Egypt, U.K., Ethiopia, France, Germany, Greece, Holland, Hungary, Iceland, Iran, Iraq, Israel, Libya, Morocco, Poland, Rumania, Russia, Switzerland, Tunisia, Turkey, Yemen, Yugoslavia. + Ordinal scales of M.s. were derived from refs. 28 and 29.

* Israeli prevalance data are taken from ref. 30 .

The independent variables come from ref. 31 
POSSIBLE BIOLOGICAL BASES FOR THE ROLE OF DAIRY PRODUCTS IN THE G.P.F.

\section{Diet and Latitude}

If we accept that the G.P.F. is related to milk consumption, we should next ask how dairy products affect the brain.

Latitude and dairy fat consumption covary. The reasons for this are multiple and include economic, veterinary, and cultural factors. ${ }^{32}$ Dairy and meat products tend to displace fish and vegetable fats in the diet in the U.S. when the choice is freely available. ${ }^{18}$ Since dairy and meat products tend to contain saturated fats and the fish and vegetables contain polyunsaturated fats, the result is a lowering of the amount of polyunsaturated fat in the diet. In this connection, it is important to reconsider the age at which the G.P.F. is established. Epidemiological studies suggest it is before adulthood. ${ }^{34}$ The perinatal period may be especially important. When the brain is still myelinating and the blood-brain barrier is not yet fully established, brain structures could be modified as a result of dietary intake. Human milk differs from cow's milk in a number of ways (see below), and there is no reason to believe that evolution would have protected us from putative damaging effects of drinking ruminant milk. The world trend away from breast feeding could result in an increase in M.S. if the G.P.F. exerts its effect via cow's milk during infancy. Clausen and Møller ${ }^{35}$ found that an essential-fatty-acid deficiency in infant guineapigs increased susceptibility to experimental allergic encephalomyelitis, an animal disease that is thought to resemble M.S.

Diet might affect the initiating events in M.S. as well as the progress of the disease throughout life. Since dietary preferences tend to be established early in life, the establishment of the G.P.F. before age 15 could simply reflect the formation of dietary habits, while the progression of the disease could reflect the consequences of maintenance of the old diet. For example, the adolescent European immigrant to Israel probably has a considerably different diet than an immigrant from Yemen.

\section{Lipids and M.S.}

That lipids in the diet can affect the progression of M.S. is not a new idea. ${ }^{36}$ For many years, Swank ${ }^{37}$ has advocated a low-fat diet, and more recently a diet high in polyunsaturated fatty acids has been reported to have beneficial effects on patients with M.S. ${ }^{38}$ Bernsohn and Stephanides ${ }^{8}$ have pointed out that these two ideas may not be contradictory, since a diet high in saturated fat could produce a relative essential-fatty-acid deficiency. Since the elongation of fatty-acid chain length in the brain seems to diminish after the developmental period of rapid myelination, ${ }^{39}$ a metabolic basis can be postulated for permanent alterations in brain lipids as a result of early diet.

Because M.S. is a demyelinating disease, there have been numerous biochemical investigations concerning the composition of myelin of normal and M.S. brain, and comparisons of plaque lipids with surrounding brain lipids in M.S. brain. ${ }^{40}$ In general, there are no striking differences between normal myelin and non- affected regions of M.S. brains. The composition of the plaque itself is intermediate between that of myelin and normal grey-matter. The region simply shows the disappearance of myelin. The question then remains, how could diet lead to the G.P.F.?

\section{Essential-fatty-acid Deficiency or Toxicity?}

A distinction should be made between the two families of essential fatty acids that man requires in his dietthose having a double bond three carbons from the methyl end ( $\omega 3$ fatty acids) typified by linolenic acid, and those having a double bond six carbons from the methyl end ( $\omega 6$ fatty acids) typified by linoleic acid. While linoleic and linolenic acids are present in very low quantities in brain, their elongated products constitute a major factor of brain fatty acids, especially in grey-matter. ${ }^{41}$ In addition to arachidonic acid $(20: 4 \omega 6)$ and docosahexaenoic acid

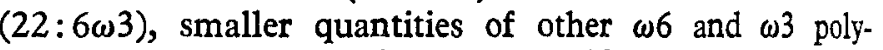
unsaturated acids are also present. The two major polyunsaturated acids constitute over $30 \%$ of the fatty acids in human grey-matter phosphatidylethanolamine, and the minor ones contribute an additional $15 \% .{ }^{42}$

The reducing atmosphere of the rumen removes linoleic and linolenic acids, so that they are virtually absent from milk. ${ }^{43}$ The combination of dairy products and ruminant meats thus reduces the total amount of polyunsaturated fatty acids in the diet. Coastal regions of Norway have a low incidence of M.S. relative to inland areas, ${ }^{44}$ in contradiction to the latitude correlation. An even more dramatic example is Japan in a high-G.P.F. zone by latitude but with little M.S. ${ }^{45}$ Since coastal communities eat a lot of fish and since fish is a good source of essential fatty acids, these observations support the idea that an essential-fatty-acid deficiency could account for the G.P.F. Our U.S. data, however, suggest strongly that dairy fat per se correlates with M.S. mortality, independent of the negative correlation with fish consumption. In other words, eating fish may protect to some extent against the G.P.F. but it does not account for the correlation of M.S. with milk consumption. We therefore next considered possible constituents of milk whose presence could account for the G.P.F.

\section{Milk Lipids}

Besides having a relatively low concentration of the polyunsaturated fatty acids, milk fatty acids are characterised by a great diversity-over 140 fatty acids have been isolated from milk, ${ }^{46}$ many of which are either unique to milk, or are present in milk in higher amounts than in any other dietary component. There is no evidence for the accretion of a storage lipid in M.S. Nevertheless, since there are at least 50 trace fatty acids in milk that have not been described in other dietary sources, they must be considered for their possible roles in the G.P.F. Such fatty acids include those with branched chains (isoand anteiso-) or odd-numbered chain lengths and hydroxy fatty acids. Most of these unusual fatty acids are produced by the rumen bacteria and are not found in human milk. ${ }^{47}$

\section{Short-chain Fatty Acids in Milk}

Short-chain fatty acids such as butyrate and hexanoate are produced by rumen bacteria and are present in milk fat (see figure). Human milk fat contains no fatty acids below $\mathrm{C}_{10 .}{ }^{47}$ Short-chain fatty acids (up to hexanoate) inhibit growth in bacterial and eukaryotic cell cultures, Such substances block transport of aminoacids: parenteral administration of short and medium chain fatty acids can produce coma in the rat, ${ }^{49}$ but the significance of this finding to human nutrition is questionable, especially since large amounts of medium-chain fatty acids (octanoate and 


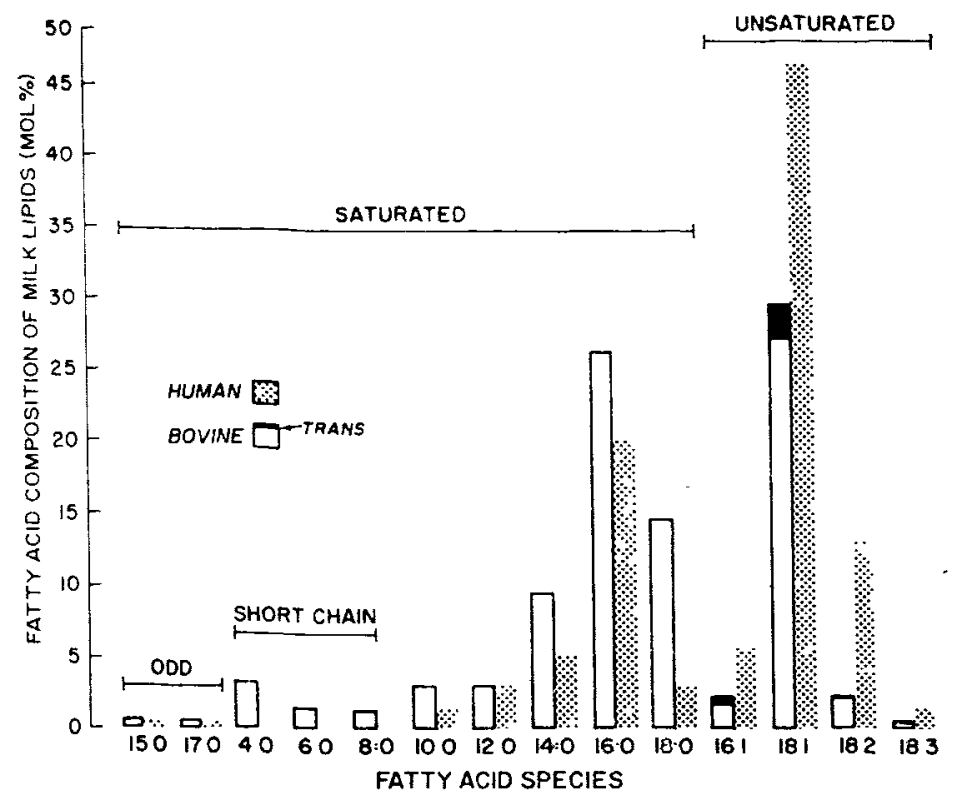

Comparison of fatty acids present in bovine and in human milk.

Bovine milk lipids contain butyric (4:0), hexanoic (6:0), and octanoic (8:0) acids, all absent from human milk. Bovine milk contains higher amounts of longer-chain saturated fatty acids and lower amounts of the unsaturated fatty acids than human milk. It also contains trans fatty acids, primarily vaccenic (18:1, 11-trans), a hexadecenoic acid (16:1, 9-trans), and traces of their positional isomers, as well as traces of various positional and geometric isomers of linoleic (18:2) and linolenic (18:3) acids.

decanoate) are well tolerated when ingested as their triglycerides in coconut oil. Whether short-chain fatty acids in the diet (butyrate or hexanoate) can produce deleterious effects, notably in the growing brain, is unknown.

\section{Vaccenic Acid}

Should there be a toxic lipid in milk that predisposes to $M . S$. , the trans fatty acid, vaccenic (18:1, 11-trans), would be an appealing candidate. Linoleic acid and linolenic acid are reduced in the rumen to a variety of substances, the most common of which is vaccenic acid. Most of our knowledge of the metabolism of trans fatty acids relates to 18:1, 9-trans (elaidic acid) formed in the industrial hydrogenation of vegetable oils. Significant amounts of dietary elaidic acid can be incorporated into human triglycerides and structural lipids. ${ }^{50}$ There are conflicting reports regarding whether or not trans acids enter the brain, ${ }^{51,52}$ and this matter should be reinvestigated. Knowledge of the geographical distribution of dietary amounts of the various trans fatty acids consumed during infancy would be very useful. Commercial hydrogenation processes used for the production of fat have varied over the past 50 years, and it is difficult to assess the relative contribution of milk fats to the total amount of dietary trans fatty acids. Since the 1950 s, most of the trans fatty acids in the U.S. diet have come via the industrial catalytic hydrogenation of polyunsaturated vegetable oils. If the G.P.F. changes in the $1980 \mathrm{~s}$, the possible role of trans fatty acids in M.S. should be considered.

HOW MIGHT DIETARY LIPIDS PREDISPOSE TO M.S.?

The defective membranes formed as a result of diet could permit easier entry by a causal agent via the blood-brain barrier or accelerate degradation of myelin itself. Short-chain fatty acids damage membranes, and trans fatty acids may be expected to produce major changes in membrane structure..$^{53}$ The freedom of motion of trans fatty acids is intermediate between that of the rigid saturated fatty acid and the flexible cis form, in monolayers such as must occur in membranes. This is reflected in the melting-points of fatty acids. It is also of some possible interest that, in cow's milk, trans fatty acid seems to be concentrated in sphingomyelin. ${ }^{54}$ This phospholipid should be examined in human tissue for its trans fatty acid content.

OTHER POSSIBLE TOXIC COMPONENTS OF MILK

We have described a number of bovine components that might be unhealthy for non-ruminants. A number of more conventionally toxic substances might also mediate the G.P.F. For example, the ingestion of peroxidised fats in stored fodder could result in their presence in milk. It is also possible that milk contains a toxic substance, such as a trace element, that produces a cumulative effect. Geological studies suggest that glaciation produced changes in the soil that could somehow lead to the G.P.F. ${ }^{55}$ Lactose could exert a chronic toxic effect. There are few other dietary sources of galactose, and since the sugar is metabolised via a specific pathway, it is possible that its ingestion long after the normal weaning age could have a deleterious metabolic effect. The known intolerance to lactose in non-Whites ${ }^{56}$ and a low-milk consumption in the non-White populations in the U.S. might account for their apparent resistance to the disease.

It has been suggested that galactose arising from dietary lactose might serve in the biosynthesis of galactocerebroside, since myelination is active during nursing, but the weight of biochemical evidence is against this. ${ }^{57}$ The carbohydrates in milk may play an important role in the immunological development of the infant. Fucosyl and sialyl lactose are also present in human milk, and in some species these sugars may even be major milk components. ${ }^{58}$ Since galactose, fucose, and sialic acid are common determinants of tissue antigens, it is possible that milk carbohydrates play an immunological role, and that the nature of the carbohydrates and the duration of their ingestion could have immunological consequences that contribute to the G.P.F. Human milk contains high concentrations of inositol, which is quite low in cow's milk. ${ }^{59}$

Xanthine oxidase, reportedly found in ruminant but not in human milk, can be absorbed into the blood. ${ }^{60}$ It has been postulated that its adventitious presence can contribute to the atherosclerotic disease process. It might also mediate the G.P.F. in M.S. An as yet unidentified factor in cow's milk has been reported to block cholesterol synthesis. ${ }^{61}$

NON-DIETARY EXPLANATIONS OF THE GEOGRAPHICAL PREDISPOSING FACTOR

The G.P.F. might be accounted for by an infectious agent such as a slow virus, transmitted by cows. Indeed, when milk production and milk consumption are simultaneously examined, both variables contribute significantly to M.S. mortality. Thus, propinquity to a large cattle population could in itself predispose to the disease. A report of prevalence of M.S. among forty occupational groups in Denmark indicated that the disease was considerably higher than expected among dairy farmers. ${ }^{62}$ The correlation could be explained by their higher dairy product consumption, but it is also possible that dairy farmers are more likely to be exposed to the putative virus by contact with the animals or through milk itself.

M.S. is not unique in having a geographical distribution. Poliomyelitis was found to have a geographical distribution negatively correlated with sanitation. ${ }^{5}$ A number of diseases are found in specific climates because of the existence of various vectors. 
While there is not yet a convincing proposal involving an infectious agent that accounts for the G.P.F. in M.S., geographically distributed genetic predisposing factors may play a role. ${ }^{63}$ M.S. is much more common among relatives of M.S. patients than the general population, and it has been proposed that HL-A antigen subtypes may carry increased risks of acquiring the disease. ${ }^{64}$ Since these antigens are distributed according to geographical patterns, it is possible that genetic subpopulations could be defined that would account for some part of the G.P.F.

Requests for repririts should be addressed to D. G., Population Studies Center, University of Michigan, 1225 South University Avenue, Ann Arbor, Michigan 40104, U.S.A.

\section{REFERENCES}

1. Kurland, T. Am. F. Hyg. 1972, 55, 457 .

2. Behrend, R. C. Eur. Neurol. 1969, 2, 129.

3. Brody, J. A. Lancet, 1972 , ii, 173.

4. Alvord, E. C. Jr. in Handbook of Clinical Neurology (edited by P. J. Vinken and G. W. Bruyn); p. 500. Amsterdam, 1970.

5. Poskanzer, D. C., Schapira, K., Miller, H. Lancet, 1963, ii, 917.

6. Kurtzke, J. F. Acta neurol. scand. 1966, 3, 577.

7. Miller, H., Ridley, A., Schapira, K. Br. med. F. 1960, ii, 343.

8. Bernsohn, J., Stephanides, L. M. Nature, 1967, 215, 821.

9. Acheson, E. D., Bachrach, C. A., Wright, F. M. Acta psychiat. scand. 1960, 35, suppl. 147, p. 132.

10. Kurtzke, J. F. in Multiple Sclerosis: Progress in Research (edited by E. J. Field, T. M. Bell, and P. R. Carnegie); p. 208. Amsterdam, 1972.

11. Mackay, R. P., Mirano, A. Archs Neurol. 1967, 17, 588.

12. Kurland, L. T., Moriyama, I. M. F. Am. med. Ass. 1951, 145, 725.

13. National Office of Vital Statistics. Vital Statistics of the United States, 1949-51, 1953-67. U.S. Government Printing Office, $1951-69$.

14. U.S. Bureau of the Census. Census of Population 1970: vol. I, characteristics of the population, part $A$, number of inhabitants; p. 48. U.S. Government Printing Office, 1972.

15. U.S. Department of Agriculture. Yearbook 1931 ; p. 889. U.S. Government Printing Office, 1931.

16. U.S. Department of Agriculture. Agricultural Statistics 1951 ; p. 388. U.S. Government Printing Office, 1952.

17. Raunikar, R., Purcell, J. C., Elrod, J. G. Spatial and Temporal Aspects of the Demand for Food in the United States; vol. I, Fluid Milk. Athens, Georgia, 1969.

18. U.S. Department of Agriculture. Food Consumption of Households in the United States, Spring 1965. U.S. Government Printing Office, 1968.

19. U.S. Bureau of the Census. Statistical Abstract of the United States 1963 ; p. 329. U.S. Government Printing Office, 1963.

20. U.S. Bureau of the Census. Statistical Abstract of the United States 1971 ; p. 670. U.S. Government Printing Office, 1971.

21. U.S. Bureau of the Census. Statistical Abstract of the United States 1947 ; p. 85 . U.S. Government Printing Office, 1947.

22. U.S. Bureau of the Census. Statistical Abstract of the United States 1973 ; p. 183. U.S. Government Printing Office, 1973.

23. New York Times Atlas of the World; p. 92. New York, 1972.

24. Oh, S. J., Calhoun, C. L. F. natn. Med. Ass. 1969, 61, 388.

25. Purcell, J. C., Raunikar, R., Elrod, J. C. Analysis of Demand for Beverage Milk. Athens, Georgia, 1968.

26. Bayless, T. M., Rosensweig, N. S. F. Am. med. Ass. 1966, 197, 968.

27. O.E.C.D. Food Consumption Statistics 1955-1971. Paris, 1973.

28. Dean, G. Sci. Am. 1970, 233, 40.

29. Acheson, E. D. in Multiple Sclerosis: a Reappraisal (edited by D. McAlpine, C. E. Lumsden, and E. D. Acheson); p. 34. Baltimore, 1965.

30. Leibowitz, V., Sharon, D., Alter, M. Brain, 1967, 90, 871.

31. United Nations Statistical Office. Statistical Yearbook 1972. United Nations, New York, 1973.

32. Leibowitz, V., Kahana, E., Alter, M. in Multiple Sclerosis: Progress in Research (edited by E. J. Field, T. M. Bell, and P. R. Carnegie); p. 179. Amsterdam, 1972 .

33. Lampert, L. Modern Dairy Products. New York, 1965.

34. Dean, G. in Progress in Multiple Sclerosis (edited by V. Leibowitz); p. 132. New York, 1972.

35. Clausen, J., Møller, J. Acta neurol. scand. 1967, 43, 375.

36. Sinclair, H. M. Lancet, 1956, i, 381.

37. Swank, R. L. Archs Neurol. 1970, 23, 460.

38. Millar, J. D., Zilkha, K. J., Langman, M. J., Wright, H. P., Smith, A. D., Belin, J., Thompson, R. H. Br. med. F. 1973, i, 765.

39. Yatsu, F. M., Moss, S. Nature, 1970, 227, 1132.

40. Suzuki, K., Kamoshita, S., Eto, Y., Tourtellotte, W. W., Gonatas, J. O. Archs Neurol. 1973, 28, 293.

References continued at foot of next column

\section{USER'S GUIDE TO SOME NEW TESTS FOR HEPATITIS-B ANTIGEN}
E. M. VANDERVELDF
N. MaHMOOD
A. Porter
C. GOFFIN
B. MEgSON
Y. E. COSSART

Virus Reference Laboratory, Central Public Health Laboratory, Colindale, London NW9 $5 \mathrm{HT}$

Summary Three commercially available tests, two hæmagglutination and one radioimmunoassay, were used to test sera received in a routine clinical laboratory and compared for reliability, convenience, and sensitivity. Their performance was very similar, and, compared with electrophoresis, the yield of positive results was increased by about $25 \%$.

\section{INTRODUCTION}

THE first-generation tests for hepatitis-B antigen (HBAg)-namely, gel diffusion, electrophoresis, and complement fixation-are now seen to be relatively insensitive, but it is not clear which of the newer more sensitive tests would be most suitable for routine use. In the Virus Reference Laboratory three commercially available tests, two hæmagglutination (H.A.) and one radioimmunoassay (R.I.A.), were compared with electrophoresis, and sera giving anomalous results were further tested by immune electron-microscopy.

\section{MATERIALS AND METHODS}

\section{Techniques}

The 'Hepanosticon' reagent ${ }^{1}$ (Organon Scientific Development Group) uses sheep erythrocytes to which

DR AGRANOFF, PROFESSOR GOLDBERG: REFERENCES -continued

41. Foote, J. L., Allen, R. J., Agranoff, B. W. F. Lipid Res. 1965, 6, 518. 42. Crawford, M. A., Sinclair, A. J. in Lipids, Malnutrition and the Developing Brain; p. 267. Amsterdam, 1972.

43. Garton, G. A. F. Lipid Res. 1963, 4, 237.

44. Presthus, J. Acta psychiat. neurol. scand. 1966, 35, suppl. 147, p. 88 45. Okinaka, S., McAlpine, D., Miyagawa, K., Suwa, N., Kuroiwa, Y., Shiraki, H., Araki, S., Kurland, L. T. Wld Neurol. 1960, 1, 22.

46. Jensen, R. G., Quinn, J. G., Carpenter, D. L., Sampugna, \} F. Dairy Sci. 1967, 50, 119.

47. Morrison, W. R. in Topics in Lipid Chemistry (edited by F. D Gunstone); vol. I, p. 3. New York, 1970.

48. Ginsburg, E., Salomon, D., Sreevasan, T., Freese, E. Proc, natn Acad. Sci. U.S.A. 1973, 70, 2457.

49. Walker, C. O., McCandless, D. W., McGary, J. D., Schenker, S. 7. Lab. clin. Med. 1970, 76, 569.

50. Johnson, P. V., Johnson, O. C., Kummerow, F. A. Science, 1957 126, 698.

51. Bickerstaffe, R., Annisum, E. F. Biochem. F. 1970, 118, 433

52. Kaufmann, H. P., Bandyopadhyay, C. Fette Seifen AnstrMittel, $1965,67,969$.

53. Decker, W. J., Mertz, W. F. Nutr. 1967, 91, 324.

54. Kuzdzal-Savoie, S., Kuzdzal, W., Langlois, D., Tremin, J. in Dietary Lipids and Postnatal Development (edited by C. Galli, G. Jacini, and A. Pecile); p. 1. New York, 1973.

55. Warren, H. V., Delavault, R. E., Cross, C. H. Ann. N. Y. Acad. Si $1967,136,657$

56. Simoons, F. J. Am. F. dig. Dis. 1969, 14, 819.

57. Linzell, J. L., Peaker, M. Physiol. Rev. 1971, 51, 564

58. Messer, M., Kerry, K. R. Science, 1973, 180, 201.

59. Burton, L. E., Wells, W. W. Devel. Biol. 1974, 37, 35.

60. Zikakis, J. P. Science, 1974, 183, 472.

61. Boguslawski, W., Wrobel, J. Nature, 1974, 247, 210.

62. Hyllested, K. Disseminated Sclerosis in Denmark. Copenhagen 1956.

63. Schapira, K., Poskanzer, D. C., Miller, H. Brain, 1963, 86, 315

64. Naito, S., Namerow, N., Mickey, M. R., Terasaki, P. I. Tissut Antigens, 1972, 2, 1. 